\title{
JAMES, SOTERIOLOGY, AND SYNERGISM
}

\author{
Alexander Stewart
}

\begin{abstract}
Summary
The history of interpretation of James has often focused on what James teaches concerning salvation in 2:14-26, and has neglected other soteriological language in the book. This study will begin by investigating the soteriological synergism of faith and works in James 2:14-26, but will proceed by examining several other ways James describes the necessary, human response to God's saving initiative throughout the book: repentance and humility, love and mercy, and perseverance and patience.
\end{abstract}

\section{Introduction}

The history of interpretation of James has often focused on what James teaches concerning salvation in the 'problematic' text of 2:14-26 and has neglected other soteriological language in the book. ${ }^{1}$ This essay, an

1 Focus on this particular passage is primarily due to James's apparent contradiction with Paul. See Matt A. Jackson-McCabe, Logos and Law in the Letter of James: The Law of Nature, the Law of Moses, and the Law of Freedom (NovTSup 100; Boston, MA: Brill, 2001): 243-52, for an extensive argument that James is directly responding to and opposing Pauline ideas. Cf. Jack T. Sanders, Ethics in the New Testament: Change and Development (Philadelphia, PA: Fortress Press, 1975): 121. Luke Timothy Johnson, The Letter of James: A New Translation with Introduction and Commentary (AB 37A; New York: Doubleday, 1995): 58-64, however, argues that Paul and James 'appear not to be talking with each other by way of instruction or correction' (64). It is likely that James is responding either to a distortion of Paul's teaching that had been reported to him or to simple moral laxness and inactivity in the growing JewishChristian communities. Cf. James D. G. Dunn, Unity and Diversity in the New Testament: An Inquiry into the Character of Earliest Christianity (3rd. edn; London: SCM Press, 2006): 271-72; Ben Witherington, Letters and Homilies for Jewish Christians: A Socio-Rhetorical Commentary on Hebrews, James, and Jude (Downers Grove, IL: InterVarsity Press, 2007): 479-80; John H. P. Reumann, Variety and Unity in New Testament Thought (The Oxford Bible Series; Oxford: Oxford University Press, 1991): 200. 
exploration of James's soteriology, will begin by investigating the synergism of faith and works in James 2:14-26, but will proceed from there to examine several other ways James describes the necessary human response to God's saving initiative: repentance and humility, love and mercy, and perseverance and patience. Our argument is that any discussion of James's soteriology must go beyond the general categories of 'faith and works' to include other factors that James discusses in relation to final salvation and judgement. The holistic human response envisioned by James primarily indicates persevering, wholehearted obedience and devotion to God. ${ }^{2}$

Despite the common negative use of the word 'synergism' in

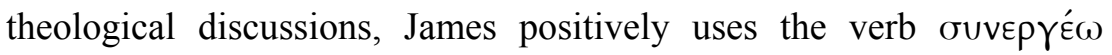
(work together with) to describe the relationship of faith and works in the reception of salvation in 2:22. Dan McCartney represents the concern of many when he argues, 'This sounds at first like "synergism", but again we must remember that James is talking not about how one obtains a relationship with God, or how a sinner may hope to receive a verdict of "not guilty" in the final judgement, but about the necessity of faith being completed by works. ${ }^{3}$ Despite the concerns of many, James does not seem to draw such nuanced distinctions between 'faith being completed by works' and final salvation.

This study describes the positive presentation of synergism in the book of James in terms of a holistic response where the adjective 'holistic' indicates an understanding of the human response to God's saving initiative that involves the entirety of a person's being and doing. This emphasis acknowledges that while we can differentiate and separate different factors of the necessary human response for the purpose of discussion and analysis (faith, works, repentance, humility, love, mercy, endurance, and patience, among other characteristics that could be added) they do not function separately soteriologically, but represent a single, unitary response of an individual to God. ${ }^{4}$

2 Dan G. McCartney, James (BECNT; Grand Rapids, MI: Baker Academic, 2009), argues that faith, understood as loyalty, is the central concern of James (267-71; esp. 267).

3 McCartney, James, 169.

4 Human being is presented as holistic in the Hebrew Bible. John Goldingay, Old Testament Theology, Volume One: Israel's Gospel (Downers Grove, IL: IVP Academic, 2003), notes 'It is not an inner journey as opposed to an outward one. That implies an antithesis alien to the First Testament, which sees our outer and inner 
Andrew Chester discusses five different approaches scholars have taken to the relationship between Paul and James. ${ }^{5}$ Because concrete evidence regarding the precise historical relationship between Paul and James is lacking, this study will approach James on its own terms, without assuming the presence or absence of interaction with the Pauline corpus. No extensive attempt is made to 'reconcile' James with Paul or broader NT theology.

\section{James 2:14-26}

James 2:14-26 will be examined by investigating the thesis of the section, the opening and closing examples of James's thesis, the meaning of key words within the section, and the historical examples James appeals to in defence of his thesis. ${ }^{6}$

\subsection{The Thesis of James 2:14-26}

The thesis of James 2:14-26 can be clearly stated: Faith without works cannot save. ${ }^{7}$ Positively, the thesis can be stated: Salvation requires both faith and works. ${ }^{8}$ This thesis can be found by looking at 2:14d ('Is such faith able to save him?'), 17 ('faith by itself, if it does not have works, is dead'), 20 ('faith without works is useless'), 22 ('faith was


works'), 24 ('a man is justified by works and not by faith alone'), and

journey as two sides of a coin. Seeing the inner as more important than the outer would contradict its vision of our human wholeness and of God's creative involvement with our whole lives.'

5 Andrew Chester and Ralph P. Martin, The Theology of the Letters of James, Peter, and Jude (New Testament Theology; Cambridge: Cambridge University Press, 1994): 47-53.

6 See Sharyn E. Dowd, 'Faith That Works: James 2:14-26', RevExp 97 (2000): 195205, for a rhetorical analysis, and John G. Lodge, 'James and Paul at Cross-Purposes? James 2,22', Bib 62 (1981): 195-213, for a structural analysis of 2:14-26.

7 Contra Ronald Fung, “Justification" in the Epistle of James' in Right with God: Justification in the Bible and the World, ed. D. A. Carson (Carlisle: Paternoster Press, 1992): 153, who comments in passing that, 'in the light of James's basic thesis in this entire pericope, which is that genuine faith will manifest itself in works (cf. 17, 26).' James's thesis is not that genuine faith will manifest itself in works, but that salvation is dependent on a human response of both faith and works.

8 Thomas R. Schreiner and Ardel B. Caneday, The Race Set Before Us: A Biblical Theology of Perseverance \& Assurance (Downers Grove, IL: InterVarsity Press, 2001): 292, write, 'Hence New Testament writers consistently admonish believers to good works, insisting that such good works are irrefragably linked to salvation. The famous passage in James 2:14-26 is a case in point and not at all unusual.' 
$26 \mathrm{~b}$ ('faith without works is dead'). ${ }^{9}$ To say that James is stressing the importance of works in a believer's life is true, but is also an understatement. The emphasis of the thesis is that works are absolutely necessary for salvation and justification.

\subsection{The Opening and Closing Examples: James 2:15-16, 26}

James uses a pair of examples to support his thesis. The first example (2:15-16) answers the opening question of the section in 2:14 which reads, 'What is the benefit ... if someone should claim to have faith but does not have works? Is such faith able to save him?' James answers the question of 2:14 by the example of a professing believer who does nothing to help naked and starving fellow believers except to verbally encourage them. James concludes the example by asking, "What is the benefit?' What good has the professing believer actually done to help his naked and starving fellow believers? Absolutely nothing. James summarises his thesis at the end of this first example by stating, 'Thus also faith by itself, if it does not have works, is dead' (2:17). There is no benefit, advantage, or use for faith without works. It is as good as dead and can accomplish nothing.

The closing example of James 2:14-26 comes in verse 26 and makes the same point. 'For just as the body without a spirit is dead, thus also faith without works is dead.' Faith without works is analogous to a body without a spirit. Works are equated with the spirit that gives life and vitality to an otherwise dead body. It is necessary to note that the point of the example is that both elements are required. A living person requires both a body and a spirit, while salvation and justification require both faith and works. Even though both are necessary, Chester argues that James prioritises works.

[W]orks are primary, at least in the sense that they are essential for justification, that is, for being accepted, and not condemned, by God in the last judgment ... faith is secondary, at least in the sense that any claim to have faith in itself counts for nothing and provides no way of being accepted in the last judgment. At the same time, however, faith is necessary, in the sense of being presupposed by, and belonging integrally together with works ... the analogy of the body and the spirit,

9 Unless otherwise noted all Biblical citations will be the author's translation based on the text of $\mathrm{UBS}^{4}$. 
shows clearly that the latter (that is, works) is the more vital, and is to be seen as superior. ${ }^{10}$

The two examples $(2: 15-16,26 a)$, along with the parallel statements that faith without works is dead $(2: 17,26 \mathrm{~b})$, function as an inclusio for the entire section, bracketing the discussion and supporting the thesis.

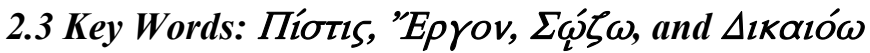

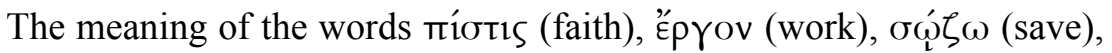
and $\delta$ ıк ı́o $\omega$ (justify) within the book of James must be carefully evaluated because it is on the level of semantics that the meaning and significance of the thesis is determined. ${ }^{11}$

James clearly views míotıs (faith) as positive and as absolutely necessary $(1: 3,6 ; 2: 1,5 ; 5: 15)$. Пíotı is used sixteen times in twelve verses in the book of James $(1: 3,6 ; 2: 1,5,14,17,18,20,22,24,26$;

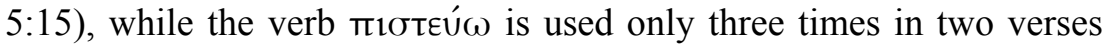
$(2: 19,23)$. The testing of faith develops perseverance (1:3). Prayer must be accompanied by faith and not doubt $(1: 6 ; 5: 15)$. Holding the faith is equivalent to living a Christian life and must not be done with partiality (2:1). God has chosen the poor to be rich in faith and heirs of the kingdom he has promised to the ones who love him (2:5). Faith can be claimed by individuals who have no works but such faith is dead and cannot save $(2: 14,17,26)$. Saving faith can only be known to exist by works (2:18). The faith of those without works is compared to the faith possessed by demons and contrasted with the faith exhibited by Abraham and Rahab $(2: 19,20,23,24)$. Finally, faith works with works and requires works in order to be complete $(2: 22)$.

Despite James's positive view of faith, James 2:14-26 represents an attempt to preserve a distinction between faith, joined to works, that is able to save from faith that is not able to save. Faith that is not able to save is characterised by right verbal and intellectual assent but lacks

10 Chester and Martin, The Theology of the Letters of James, Peter, and Jude, 23-24, (italics original).

11 Almost every study of the relationship of Paul and James focuses on the different uses of these words. See Joachim Jeremias, 'Paul and James', ExpTim 66 (1955): 36871, and Robert H. Stein, "'Saved by Faith [alone]" in Paul Versus "Not Saved by Faith Alone" in James', SBJT 4 (2000): 4-19, as good representatives. See Alister E. McGrath, Iustitia Dei: A History of the Christian Doctrine of Justification (3rd edn; Cambridge: Cambridge University Press, 2005), and A. N. S. Lane, Justification by Faith in Catholic-Protestant Dialogue: An Evangelical Assessment (London: T\&T Clark, 2002) for excellent historical theological discussions of justification, faith, and works. 
right action $(2: 18 \mathrm{a}, 19)$. Even demons possess faith that consists only of right thinking or believing (2:19). Works are what complete faith and make it salvific (2:22). They are what give life to the dead faith of verbal and intellectual assent $(2: 26){ }^{12}$

"Eprov (work) is always used positively in James. 'Eprov occurs twice in the singular $(1: 4,25)$ and thirteen times in ten verses in the plural $(2: 14,17,18,20,21,22,24,25,26 ; 3: 13)$. Endurance must have its complete work (1:4); the doer of work is contrasted to the hearer who forgets (2:25); wisdom is demonstrated by works further defined as good conduct in contrast to resentful jealousy and selfish ambition (3:13); works are necessary to complete and bring life to faith and to secure salvation and justification $(2: 14,17,18,20,21,22,24,25,26)$.

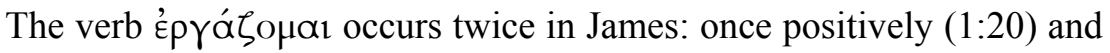
once negatively (2:9). Anger is condemned because it does not work (produce) the righteousness of God (1:20); those who show partiality work (commit) sin and are convicted as transgressors of the law to love your neighbour as yourself (2:9).

'Epra (works) is clearly defined in 3:13 as 'good conduct' ( $\mathrm{k} \alpha \lambda \tilde{n}$ S

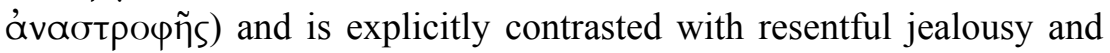
selfish ambition (3:14). It is in 1:19-27 however, that James clearly communicates what he means by "̌p $\alpha$ a through the contrast between the hearers and the doers. This contrast in 1:19-27 illuminates James's teaching in 2:14-26. The 'hearers' are the ones who believe that 'God is one' along with the demons (2:19) but who fail to join their faith to works for salvation as Abraham and Rahab, the 'doers', did (2:21-25). James 1:19-26 describes 'doing' as being slow to anger (1:19), working the righteousness of God (1:20), putting away all moral impurity and wickedness (1:21), doing the word (1:22-25), exercising self-control over speech (1:26), taking care of orphans and widows (1:27), and keeping oneself unstained from the world (1:27). Chapter 2 further defines "́p $\gamma \alpha$ as showing no partiality between the rich and poor $(2: 1-$ 13) and helping fellow Christians in their poverty with food and clothing (2:15-16).

James's understanding of 'works' (good conduct; putting away anger, moral impurity, and wickedness; speaking rightly; keeping

12 Adolf von Schlatter, Der Brief des Jakobus (2nd edn; Stuttgart: Calwer Verlag, 1956): 188, rightly notes that, "das Bekenntnis: „Ich habe Glauben“ nur dann Sinn und Wert hat, wenn der Glaubende auch Werke hat' ('The confession "I have faith" only has significance and worth if the believer also has works.' Author's translation). 
oneself unstained by the world) is equivalent to obedience to God's law and can be legitimately linked to modern theological discussions of sanctification. ${ }^{13}$ Paul likewise often positively linked faith and works (Rom. 1:5; 2:6-8; 6:17-18; 1 Cor. 13:2; Gal. 5:6; 6:7-10; 1 Thess. 1:3). ${ }^{14}$ 'Works' in James nowhere indicates a focus on the ritual or ceremonial aspects of the Torah. ${ }^{15}$

$\sum \omega ́ \zeta \omega$ (save) is used five times $(1: 21 ; 2: 14 ; 4: 12 ; 5: 15,20)$ while the noun owrnpía (salvation) does not occur in James. ${ }^{16}$ The first occurrence in 1:21 follows the command to receive the implanted word which is able to save $(\sigma \tilde{\omega} \sigma \alpha 1)$ your souls. The following verses describe how one receives the word: by doing it (1:22-25). This statement that the salvation of their souls was dependent on receiving the word, further defined as doing the word, is followed in 2:14 by the question concerning whether faith without any works was able to save ( $\left.\sigma \tilde{\omega} \sigma \alpha_{1}\right)$. James clearly answers in the negative. In 4:11-12 James instructs believers not to judge each other because there is only one judge who is able to save $\left(\sigma \tilde{\omega} \sigma \alpha_{1}\right)$ and to destroy. In 5:15 it is said that the prayer of faith will save ( $\sigma \omega \sigma \sigma \varepsilon)$ the one who is sick: the Lord will raise him up and his sins will be forgiven. The use of $\sigma \omega \hat{L} \zeta \omega$ in 5:20 is similar to 5:15 in the pairing of salvation with forgiveness of sins. The one who turns a sinner from the perversion of his way will save ( $\sigma \omega ́ \sigma \varepsilon 1)$ his soul from death and will cover a multitude of sins.

The usage of $\sigma \omega \zeta \omega$ throughout James indicates that it is used to refer 'to the entire process that begins with initial faith in Christ and climaxes in heavenly glorification'. ${ }^{17}$ The mention of eschatological

13 Ron Julian, 'A Perfect Work: Trials and Sanctification in the Book of James', SBJT 4 (2000): 40-50, and Wil L. Owens, 'The Doctrine of Sanctification with Respect to Its Role in Eternal Salvation' (Ph.D. dissertation, Southeastern Baptist Theological Seminary, 2008): 153, both make a connection between 'works' in James and progressive sanctification.

14 Cf. Laato, 'Justification according to James', 72; Klyne Snodgrass, 'Justification by Grace - to the Doers: An Analysis of the Place of Romans 2 in the Theology of Paul', NTS 32 (1986): 72-93.

15 James qualifies his understanding of the law with the designation 'royal law' (2:8) and 'law of freedom' (1:25 and 2:12) and indicates the content of the law by means of the love command (2:8-11). See Timo Laato, 'Justification according to James: A Comparison with Paul', TJ 18 (1997): 66.

16 Gale Z. Heide, 'The Soteriology of James 2:14', GTJ 12 (1991): 69-97, conducts a thorough and cogent analysis of salvation in 2:14 and concludes that it points to eternal, not temporal, salvation. Ralph P. Martin, James (WBC 48; Waco, TX: Word Books, 1988): 81, among many other commentators, argues likewise.

17 Craig L. Blomberg and Mariam Kamell, James (Zondervan Exegetical Commentary on the New Testament; Grand Rapids, MI: Zondervan, 2008): 129. 
salvation in 1:21 and the connection with forgiveness of sins in 5:15 and 5:20 indicate that salvation in James cannot be limited to earthly, physical salvation or rescue, but maintains a future, eschatological referent (cf. the eschatological orientation of the letter in 1:9-12, 21; $2: 5 ; 12-13 ; 3: 1 ; 4: 12 ; 5: 3,7-9,12){ }^{18}$

$\Delta$ k kaló $\omega$ (justify) is used three times in the book of James $(2: 21,24$,

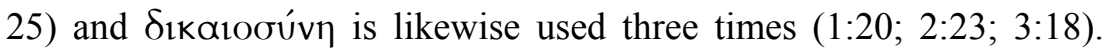
There are three common interpretations of James's use of $\delta$ เкaı́ $\omega .{ }^{19}$ First, it is referring completely to justification before men and is not soteriological. ${ }^{20}$ Second, it means to 'show to be righteous' and thus carries an exclusively demonstrative sense. ${ }^{21}$ Works justify someone in the sense that they give evidence of the presence of saving faith. ${ }^{22}$ Third, it is referring to final, eschatological justification. ${ }^{23}$

The first two explanations, that justification is simply demonstrative evidence of saving faith or a justification before men, fail to adequately account for the way James uses salvation and justification as virtual synonyms. James begins this section $(2: 14-26)$ by discussing whether faith without works could save. He ends the section by discussing if faith without works could justify. The change in terminology from salvation to justification is due to the introduction of Abraham as evidence and the use of $\delta$ ıкaıơúv $\eta$ in Genesis 15:6 (LXX). Despite

18 Zane Clark Hodges, The Epistle of James: Proven Character Through Testing: A Verse by Verse Commentary (The Grace New Testament Commentary; Irving, TX: Grace Evangelical Society, 1994): 41-42, argues that salvation in James is completely physical and that $\psi \cup \chi \eta$ ' should be translated as 'life'. While it is true that 'salvation' can refer to physical rescue or healing depending on the context, the eschatological tone of the letter does not make that likely in James. Furthermore, James uses $\zeta \omega \eta$ in 4:14 to refer to physical life, not uvхп́. Douglas J. Moo, The Letter of James: An Introduction and Commentary (The Pillar New Testament Commentary; Grand Rapids, MI: Eerdmans, 2000): 124, writes, 'Clearly, we must give the verb the full theological force that it normally has in the NT epistles (of the thirty occurrences of "save" outside of James in the NT epistles, twenty-nine clearly refer to eschatological deliverance, the possible exception being Heb. 5:7).'

19 McCartney, James, 162-68, discusses seven possible interpretations but dismisses most of them quickly and focuses on the demonstrative and future verdict options.

20 Hodges, The Epistle of James, 66-67; Charles Caldwell Ryrie, So Great Salvation: What It Means to Believe in Jesus Christ (Wheaton, IL: Victor Books, 1989): 132-33.

21 Blomberg and Kamell, James, 136; Fung, 'Right with God', 153.

22 C. Ryan Jenkins, 'Faith and Works in Paul and James', BSac 159 (2002): 70.

23 Ben Witherington, Letters and Homilies for Jewish Christians, 478; Stein, 'Saved by Faith [Alone]', 13; Moo, The Letter of James, 134. 
the change in terminology, the concept is unified throughout the section. ${ }^{24}$ Can faith without works save/justify someone? ${ }^{25}$

Douglas Moo likewise rejects the interpretation of justification in James 2:21-25 as 'demonstrated to be right'.

Harmony with Paul is quite clear if this second meaning is adopted. But we question whether it is the most likely. Not only is 'show to be right' a fairly rare use of the verb, but the meaning does not fit the context as well. To be sure, advocates of the 'show to be righteous' interpretation can point to v. 18, where James challenges his opponent to 'show' him his faith. But, as we commented on that verse, 'show' probably has the sense 'prove' rather than 'reveal.' More important is the overall thrust of this passage, established by the broader context, in which the issue is what constitutes the 'true religion' that will survive the judgment of God $(1: 21-27 ; 2: 12-13)$ and by the specific question raised in v. 14 : will 'that kind of faith' save a person? ${ }^{26}$

Justification in James primarily represents the vindicating verdict from the eschatological judge $(4: 12 ; 5: 7-9)$ resulting in eschatological salvation. ${ }^{27}$ This future verdict can be anticipated in a person's lifetime in the present through their works. ${ }^{28}$

24 Robert V. Rakestraw, 'James 2:14-26: Does James Contradict the Pauline Soteriology?', CTR 1 (1986): 42, argues that even though justification in James is declarative-judicial the 'focus is upon the declaration by God (and perhaps by people) during a believer's lifetime that he or she is truly a righteous person (e.g. Jas 2:21, $25)$ '. This suggestion is unlikely because of the near synonymous usage of 'salvation' and 'justification' in James.

25 Schreiner and Caneday, The Race Set before Us, 293, rightly comment, 'It is highly artificial, in our opinion, to argue that salvation and justification in James do not relate to eternal life and justification before God. There is no indication that James uses the terms save and justify with a meaning different from Paul's' (italics original).

26 Moo, The Letter of James, 135. McCartney, James, 168 is right to note that 'it may be most faithful to James to suppose that he would not have drawn a sharp line between the notions of a demonstration of righteousness and God's verdict of righteousness'. McCartney, nevertheless, seems to favour a demonstrative sense for justification over final justification (162-70).

27 Contra R. T. Kendall, Once Saved, Always Saved (Biblical Classics Library; Carlisle: Paternoster Press, 1997): 170, who writes, 'James's statement about being justified by works was not with reference to salvation at all; it referred to an indiscriminate love for all men.'

28 Martin Dibelius, James: A Commentary on the Epistle of James (Hermeneia; Philadelphia, PA: Fortress Press, 1976): 162, rightly notes how, according to James, Abraham received God's approval on the basis of his works during his lifetime and 'not merely at the final judgment'. 


\subsection{Historical Examples: Abraham and Rahab}

James adds further support for his thesis with the historical examples of Abraham and Rahab. Abraham is well known for his faith and hospitality in Second Temple literature, and the events of his life are often discussed without regard to chronology, similarly to how James merges Genesis 15:6 with Genesis 22 (1 Macc. 2:52; Jub. 23:10; Pr. Man. 8; Sir. 44:19-20; 2 Bar. 57:2; L.A.B. 18:5; Abraham, 167). ${ }^{29}$ Nehemiah 9:7-8 presents a canonical interpretation of Abraham's life that pairs Genesis 15:6 with 17:5 and links Abraham's faithfulness to God's covenant with him.

When the history of interpretation of Genesis 15:6 is kept in mind, James's use of the verse in connection with Genesis 22 in his argument to prove that justification is based on works and not faith alone seems completely natural. ${ }^{30} \mathrm{He}$ is using Genesis $15: 6$ as a narrative theological summary of Abraham's entire life, building upon an Old Testament understanding of righteousness as ethically declared on the basis of the facts, the previous canonical interpretation of Genesis 15:6 in Nehemiah 9:7-8, and the general interpretation of Abraham's life current in his culture and presupposed by his hearers. ${ }^{31}$ James is on firm hermeneutical ground in his use of Abraham to demonstrate the necessity of works.

James mentions Rahab's justification by works without any reference to faith at all (2:25). While this is a significant indication of his emphasis on the importance and even priority of works as a saving response to God's gracious implanted word, it should not be used to argue that James saw no need for faith. ${ }^{32}$ The use of níotıs throughout the letter clearly indicates that it is equally necessary as a saving response to God's grace. Faith and works are both necessary because they work together (бuvíprє1, 2:22). ${ }^{33}$

29 See Irving Jacobs, 'The Midrashic Background for James 2:21-23', NTS 22 (1976): 457-64, who helpfully discusses 'the rabbinic maxim "There is no 'earlier' or 'later' (i.e. strict chronological order) in the Torah"” (463).

30 Moo, The Letter of James, 135, states, 'James is asserting that Abraham was granted a positive verdict in the judgment by God on the basis of his pious acts.'

31 James's dependence on Second Temple literature is both obvious and selective. James did not endorse Abraham's perfection or speculate concerning his keeping of the whole law before it was given.

32 Dibelius, James, 166, highlights how the absence of any reference to Rahab's faith is remarkable.

33 Contra Kendall, Once Saved, Always Saved, 19, who writes, 'Whoever once truly believes that Jesus was raised from the dead, and confesses that Jesus is Lord, will go 


\section{God's Saving Initiative and Mankind's Holistic Response}

This emphasis on the necessity of works does not necessarily make human actions meritorious. Some scholars attempt to alleviate the apparent tension over this point by arguing that James discusses the necessity of post-conversion works while Paul focuses on the soteriological futility of pre-conversion works. ${ }^{34}$ While this difference is theoretically helpful, it is unlikely that James would have recognised such a difference. Salvation, at every stage, required both God's saving initiative in bringing Christians forth by the word of truth (1:18) and their reception of that word (1:21) through faith, works, repentance, humility, love, mercy, perseverance, and patience (see below). The human response in James is the same for both 'getting in' and 'staying in'.

James argues that salvation is the result of God's will to bring forth believers by the word of truth $(1: 18) .{ }^{35}$ Salvation is dependent on God's will (1:18), choice (2:5), mercy ('€’ $\lambda \in O \varsigma, 2: 13)$, grace (4:6), compassion (5:11), mercy (oiktíp $\mu \omega v, 5: 11$ ), and forgiveness $(5: 15$; cf. 5:20). God is the one who accomplishes salvation and generously gives the wisdom from above that leads to salvation to all who ask (1:5). Alongside God's saving initiative, James clearly teaches that there is a necessary human response. ${ }^{36}$ Shortly after James discusses

to heaven when he dies. But I will not stop there. Such a person will go to heaven when he dies no matter what work (or lack of work) may accompany such faith' (italics original). It is hard to see how Kendall would escape James's scathing critique of faith without works in 2:14-26.

34 Rakestraw, 'James 2:14-26', 38-39, writes concerning the use of 'works' in James and Paul, 'The difference between them is in the context in which these works are done-in the sequence of works and conversion. "Paul denies any efficacy to preconversion works, but James is pleading for the absolute necessity of post-conversion works" (italics original, quoting Moo, James, 102). Cf. P. J. Hartin, James (SP; Collegeville, MN: Liturgical Press, 2003): 166-67. Alan P. Stanley, Did Jesus Teach Salvation by Works?: The Role of Works in Salvation in the Synoptic Gospels (The Evangelical Theological Society Monograph Series 4; Eugene, OR: Pickwick, 2006): 335 , likewise argues that the difference between pre- and post-conversion works is the key to reconciling the Synoptics and Paul.

35 Cf. Laato, 'Justification According to James', 48-61, 67; James B. Adamson, James: The Man and His Message (NICNT; Grand Rapids, MI: Eerdmans, 1989): 21112.

36 Edmund K. Neufeld, "The Gospel in the Gospels: Answering the Question "What Must I do to be Saved?" from the Synoptics', JETS 51 (2008): 267-96; esp. 267, distinguishes between (1) the basis on which God grants salvation, (2) how God acts to bring people to salvation, and (3) what response is required to receive what God offers. 
God's gracious action to bring forth believers by his word of truth (1:18), he commands believers to 'receive with meekness the implanted word, which is able to save your souls' $(1: 21 \mathrm{~b})$. The question becomes, 'What human response is necessary to receive God's implanted word?' In addition to the emphasis in James on faith and works as necessary elements of a saving human response, several other necessary elements are highlighted in the text. This study will focus on six primary elements in pairs of two: repentance and humility, love and mercy, and perseverance and patience.

\subsection{Repentance and Humility}

'Therefore, having put off all filthiness and abundant wickedness, receive with meekness the implanted word, which is able to save your souls' (Jas 1:21).

'Therefore, it says, 'God opposes the proud, but gives grace to the humble' (Jas 4:6b).

In James's foundational command to receive the word in 1:21 the

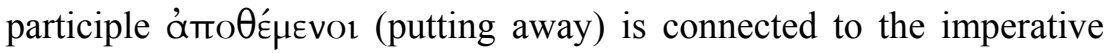
'receive', and although the participle is often translated as an independent imperative, it should be understood as temporal ('having put off'). ${ }^{37}$ The reception of God's saving, implanted word must be accompanied by repentance: the putting off of all moral filth and wickedness $(1: 21) \cdot{ }^{38}$

Repentance as necessary for salvation in the final judgement is paired with humility and further emphasised in 4:6-5:12. The quotation of Proverbs 3:34 in James 4:6 establishes the fact that God gives grace

Neufeld proceeds to argue that the basis of salvation is the merits of Jesus and the atonement he accomplished, the means of salvation used by God include 'electing, convicting, calling, and enabling', and the human response required for salvation is active obedience (he restricts his answer to this third point to the Synoptics, but it would likewise apply to James).

37 The participle certainly carries imperatival force because of its grammatical dependence on an imperative, but its subordination also indicates it should not be translated as a stand-alone imperative. Martin, James, 48, and Moo, The Letter of James, 86, along with the ESV translate the participle as a separate imperative. See, however, Blomberg and Kamell, James, 87.

38 Darian Lockett, Purity and Worldview in the Epistle of James (Library of New Testament Studies 366; London: T\&T Clark, 2008): 109, writes, 'Consequently the notion of "putting off" should not be viewed as "conversion" language but as "repentance" language.' Jackson-McCabe, Logos and Law in the Letter of James, 188, likewise notes that "it emerges from the letter as a whole that the author aims to induce in his intended audience something more appropriately characterized as "repentance" than as "conversion".' 
to the humble and threatens God's judgement to the proud who will not repent in humility. James proceeds to exhort the community to submit to God, resist the devil, draw near to God, and humble themselves before the Lord by cleansing their hands, purifying their hearts, and mourning and weeping in complete wretchedness (4:7-9).

The writer is calling upon the readers to place themselves in the state in which God, when he comes to judge, desires to find his people. God will oppose the proud, and thus the believer must be found humble. The state of 'wretchedness' is obviously a metaphor for calling the community back to God in light of the coming judgment. The language is in the style of a call to repentance. . . Thus 4.7-12 forms a coherent set of admonitions and warnings to the community members in order to prepare them for the imminent return of the judge. ${ }^{39}$

This call to repentance in humility comes with the promise that God, the judge who is able to save and destroy (4:12), and whose coming is imminent, will exalt them (4:10). Eschatological imminence is emphasised by how the community was living in the last days (5:3), the day of slaughter (5:5), when the coming of the Lord was near (5:8), and the judge was actually already standing at the door (5:9). ${ }^{40}$ Within this eschatological context both 'grace' (4:6) and the promise of exaltation (4:10) become synonymous with final salvation. ${ }^{41}$ Those who respond, and keep responding, to God with repentance and humility will receive God's grace in the future day of judgement and will experience exaltation (salvation).

39 Todd C. Penner, The Epistle of James and Eschatology: Re-Reading an Ancient Christian Letter (JSNTSup 121; Sheffield: Sheffield Academic Press, 1996): 171.

40 See Penner, The Epistle of James and Eschatology for further discussion of the pervasive presence of eschatological themes throughout James.

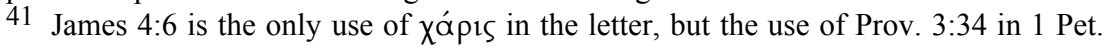
5:5-6 is instructive at this point. In 1 Pet. 5:5-6 God's opposition to the proud and giving of grace to the humble is used to motivate humility before God in order that he

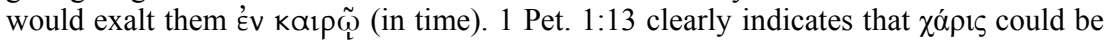
understood eschatologically when Peter commands them to 'set your hope fully on the grace to be given you when Jesus Christ is revealed'. This would seem to indicate that Peter interpreted 'grace' in his quotation from Prov. 3:34 to point to exaltation in the last time (cf. 1:5 and the emphasis on future glory throughout the chapter in 5:1, 4, and 10). John Hall Elliott, 1 Peter (AB 37B; New York: Doubleday, 2000): 850, explains that 'As in 4:18, the author gives an eschatological orientation to conventional wisdom expressed in a proverb.' For a similar eschatological understanding of grace see $2 \mathrm{Bar}$. $82: 2$, 'that the end which the Most High prepared is near, and that his grace is coming, and that the fulfillment of his judgment is not far'. Translated by A. F. J. Klijn in The Old Testament Pseudepigrapha, (vol. 1; James H. Charlesworth; Garden City, N.Y.: Doubleday \& Company, Inc., 1985): 649. 


\subsection{Love and Mercy}

'[T]he crown of life which he promised to those who love him' (1:12b).

'[T] he kingdom which he promised to those who love him' $(2: 5 \mathrm{~b})$.

'For judgment is merciless to the one who has not done mercy' (2:13a).

Both the eschatological crown of life (1:12) and the eschatological kingdom (2:5) are promised to those who love (áramá $\omega)$ God. ${ }^{42}$ The identical wording of 'he promised to those who love him'

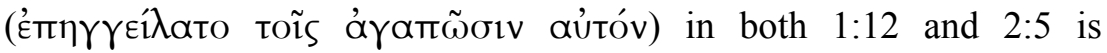
striking. Early Christians often used the image of the 'crown' to describe eschatological reward (1 Cor. 9:25; 2 Tim. 4:8; 1 Pet. 5:4; Rev. 2:10; 3:11. Cf. 2 Bar. 15:8; T. Benj. 4:1; 4 Macc. 17:11-15). The eschatological nature of the kingdom in James 2:5 is evident from the fact that the 'heirs' had not yet inherited it, but it was still future and remained as a 'promise'. Love for God is assumed to be a necessary condition for this final salvation in James. Love for God is also presented as foundational to relationship with God elsewhere in Scripture (Deut. 6:5; 10:12; 11:1, 13, 22; 13:3; 19:9; 30:6, 16, 20; Josh. 22:5; 23:11; Matt. 22:37; Mark 12:30; Luke 10:27). Deuteronomy presents love for God as inseparably connected with obedience to God in a way that could be described as holistic (with all the heart, soul, and might).

The third and final use of the verb óramá $\omega$ in James broadens the scope of love from God to one's neighbour (2:8). ${ }^{43}$ This is the 'royal law' that is broken when community members show partiality and dishonour the poor (2:9; cf. 2:6). Love for neighbour is further clarified as mercy (2:13; negatively exemplified in $2: 15-16)$. Final judgement will be without mercy to those who have shown no mercy, but those who have shown mercy will experience God's mercy in judgement $(2: 13) .{ }^{44}$ 'In $2: 13$, at the end of the section on partiality, the issue of

42 The connection of God's election with the poor (2:5) and God's judgement with the rich (5:1-6) does not indicate absolute salvation and judgement based on one's economic position. The poor are qualified as rich in faith (2:5), while the rich are qualified as blaspheming God's name (2:7) and oppressing and murdering the poor and righteous (5:4-6). Despite that fact, James does teach the blessedness of the poor and the precarious situation of the rich in light of the great eschatological reversal, wherein God will oppose the proud but give grace to the humble (4:6).

43 Cf. how Jesus likewise builds a command to love your neighbour as yourself upon the command to love God (Matt. 22:37-40; Mark 12:30-31).

44 Similar to this, in the parable of the sheep and goats in Matt. 25:31-46, Jesus equates actions towards others with actions toward himself. This then becomes the 
whether or not the poor and weak are treated with mercy is made the decisive factor for the final judgment. ${ }^{45}$ James presents love for God and for others, evidenced by acts of mercy, as necessary for final salvation. The connection between one's treatment of others and eschatological judgement is present elsewhere in James in the threats to the rich who will be condemned because they oppressed the poor $(5: 1-$ 6), the command not to grumble against each other in order not to be judged (5:9), the worthless religion associated with an unbridled tongue (1:26), the incompatibility of a tongue that both blesses God and curses men (3:1-12), and the warning against speaking evil against each other (4:11-12). Jesus likewise affirmed that love for God and neighbour accurately summarises what must be done to inherit eternal life (Luke 10:25-27).

\subsection{Perseverance and Patience}

'Blessed is the man who perseveres in trial, because when he has stood the test, he will receive the crown of life, which he promised to those who love him' (Jas 1:12).

'Behold, we consider blessed those who persevered' (Jas 5:11a).

The letter begins with a call to joy in trials because the testing of one's faith through trials results in perseverance (i்oнoví). The readers are exhorted to let perseverance have its perfect work in their lives so that they would be mature (perfect) and complete, lacking nothing. In 1:12 those who persevere in trials are declared 'blessed' because once they have been tested and approved they will receive the eschatological crown of life. ${ }^{46}$ Final salvation is dependent upon first being approved through perseverance in trials.

Steadfastness ensures that at the end-time judgment the believer is found 'perfect', 'complete', and 'lacking in nothing'. The notion of perfection is central to understanding the thrust of the opening section, for it is only through remaining steadfast that perfection is achieved, and only those will be saved who stand 'complete' on judgment day. ${ }^{47}$

basis for eschatological salvation or judgement. See Stanley, Did Jesus Teach Salvation by Works?, 330-32, for further discussion of this point.

45 Chester and Martin, The Theology of the Letters of James, Peter, and Jude, 34.

46 The necessity of perseverance is a common NT theme. Note particularly the clear statement by Jesus in Matt. 10:22 (cf. Matt. 24:13; Luke 21:19) that 'The one who endures to the end will be saved.'

47 Penner, The Epistle of James and Eschatology, 198. 
The connection of blessedness with perseverance is linked with patience and further developed in 5:7-11. In 5:7 the readers are exhorted to be patient until the coming of the Lord. This exhortation to patience is reiterated in 5:8 and paired with a command to strengthen their hearts because the coming of the Lord is near. James provides examples of this from patient farmers (5:7), the prophets who spoke in the name of the Lord (5:10), and Job (5:11). The latter two examples surround the statement, 'Behold, we consider blessed those who persevered.' Within the context of the Lord's swift coming, 'blessedness' seems to indicate eschatological blessedness (cf. the pairing of 'blessed', perseverance, and the crown of life in 1:12). ${ }^{48}$ The necessity of perseverance is further highlighted by its prominence at the opening and closing of the letter $(1: 3-4,12 ; 5: 7-11) .{ }^{49}$ The one who will be saved must patiently persevere in obedience.

\section{Summary and Conclusion}

The phrase 'holistic response' seems to adequately reflect the synergism advocated by James in his emphasis on faith, works, repentance, humility, love, mercy, perseverance, and patience as the necessary human response to God's gracious initiative in salvation. ${ }^{50}$ The emphasis in James is not on conversion, but on perseverance; the securing of salvation in the last day by the continuation (cf. the

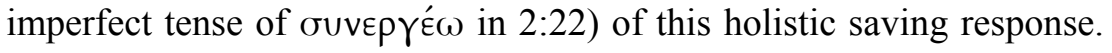
While James 1:18 does point to conversion and the new birth, the emphasis throughout James is the attainment of eschatological

48 Martin, James, 193, commenting on the aorist tense of the participle úroprívavtas, ('the ones who endured'; 5:11) notes '[t]his thought implies that this particular blessing of God is delayed for those still alive. Only those who have endured until the end can be called blessed by others. ... In other words, those who have gone into God's presence are the truly blessed.' Chester and Martin, The Theology of the Letters of James, Peter, and Jude, 19, note that '[i]n 1.12 by contrast, the positive theme of blessing is invoked for the one who comes through the eschatological testing. That is, the beatitude form is used in order to express the promise of divine, eschatological reward' (italics original).

49 Penner, The Epistle of James and Eschatology, 201.

50 Fung, 'Right with God', 156, is representative of many who explain faith as the cause of works in Jas 2:14-26. James, however, does not indicate a causal relationship but rather a relationship in which faith is on the same level of the other necessary elements of a holistic response to God's salvation. See especially Donald Verseput, 'Reworking the Puzzle of Faith and Deeds in James 2:14-26', NTS 43 (1997): 97-115, for arguments against a causal relationship. 
justification in the final judgement by engaging in a lifestyle of active reception of the word which is able to save (1:20). The true religion that God accepts is action (1:27).

This understanding of mankind's response can be equated to modern theological discussions of progressive sanctification: the progressive 'living out' of whole-hearted, single-minded devotion to God, renouncing of sin, and growth in purity and righteousness. Richard Bauckham argues that the "overarching theme of James is "perfection" or "wholeness" (1:4). Wholeness requires wholehearted and singleminded devotion to God, and its opposite is that half-heartedness in devotion to God and that divided loyalty, vacillating between God and the world, which James calls double-mindedness $(1: 8 ; 4: 8) .{ }^{51}$ Such a holistic response to God's initiative of grace in Christ will result in final salvation through its perseverance to the end. ${ }^{52}$ James views salvation as a process that begins in the present with conversion but awaits its ultimate fulfilment and vindication in the return of Christ and the age to come.

Schreiner and Caneday helpfully note that, "[f]or many evangelicals, salvation is punctiform. That is to say, they conceive of salvation as a point, not a continuum that includes beginning, process and consummation." 53 In contrast, the New Testament authors discuss salvation with reference to the past, present, and future. Christians have been saved (Rom. 8:24; Eph. 2:5, 8; 2 Tim. 1:9; Tit. 3:5), are being saved (1 Cor. 1:18; 15:2; 2 Cor. 2:15; 1 Pet. 1:9; 3:21), and finally, will be saved (Matt. 10:22; Rom. 5:9-10; 13:11; 1 Cor. 3:15; 5:5; 1 Thess. 5:8-9; 1 Tim. 4:16; 2 Tim. 4:18; Heb. 1:14; 9:28; 1 Pet. 1:5; 2:2). According to James, believers are not finally saved until the final judgement and what they 'do' between the present and that future day

51 Richard Bauckham, James: Wisdom of James, Disciple of Jesus the Sage (London: Routledge, 1999): 165. See Lockett, Purity and Worldview in the Epistle of James, for a helpful elaboration of this idea of 'perfection' in relation to the purity language of James.

52 The following texts support the necessity of works, sanctification, or perseverance in the attainment of eternal salvation. Matt. 25:31-46; John 8:31; 15:5-6; Rom. 2:6-10; 8:12-14; 1 Cor. 6: 9-11; 9:24-27; Gal. 5:19-21; 6:7-8; Eph. 5:5-10; Phil. 2:12-13; Col. 1:21-23; 1 Thess. 4:1-7; 2 Thess. 2:13-17; Heb. 12:14; 2 Pet. 1:10-11; 1 John 1:6; 2:3, 4, 9, 15, 29; 3:1-3, 6, 7, 8, 9, 10; Jude 20-24; Rev. 2:10-11. Russell Shedd, 'Justification and Personal Christian Living' in Right with God: Justification in the Bible and the World, ed. D. A. Carson (Carlisle: Paternoster Press, 1992): 176, notes that, 'The claim that justification can be genuine without the confirmation of sanctification is a dangerous deception.'

53 Schreiner and Caneday, The Race Set before Us, 147. 
actually carries soteriological weight and will affect the outcome of the verdict. Mankind's holistic response does not merit or earn salvation but is the appropriate and necessary reception of God's gracious initiative of salvation because it engages humans at every level of their being: thoughts, choices, words, and actions. 